\title{
PERLINDUNGAN HUKUM BAGI BIDAN DALAM PERTOLONGAN PERSALINAN PENDERITA HIV/AIDS DITINJAU DARI UNDANG - UNDANG REPUBLIK INDONESIA NOMOR 36 TAHUN 2014 TENTANG TENAGA KESEHATAN
}

\author{
Pemi Novita Sari \\ Mahasiswa Pasca Sarjana Unisba Program Studi Magister Ilmu Hukum \\ Email: peminovitasari@gmail.com
}

\begin{abstract}
Abstrak: Kasus HIV/AIDS merupakan fenomena gunung es, yang muncul ke permukaan hanya sebagian kecil dari yang sebenarnya. Bidan dalam melakukan pertolongan persalinan terhadap pasien yang mengidap HIV/AIDS memiliki resiko tinggi tertular HIV/AIDS saat melakukan pertolongan persalinan. Penelitian ini bertujuan untuk mengetahui dan menganalisis perlindungan hukum bagi bidan dalam proses pertolongan persalinan penderita HIV/AIDS ditinjau dari Undang-Undang Republik Indonesia Nomor 36 Tahun 2014 Tentang Tenaga Kesehatan. Penelitian ini menggunakan metode pendekatan yurudis normatif. Spesifikasi penelitian ini ialah deskriptif analisis. Data yang digunakan ialah data primer berupa data yang langsung diperoleh dari narasumber dan data sekunder yang terdiri dari bahan-bahan hukum primer, bahan hukum sekunder, dan bahan hukum tersier. Teknik pengumpulan data yang digunakan adalah studi lapangan dan studi kepustakaan. Data yang diperoleh dianalisis menggunakan metode yuridis kualitatif. Hasil penelitian yang dilakukan diperlukan ketentuan hukum yang dapat melindungi bidan dalam pertolongan persalinan penderita HIV/AIDS sedangkan Instrumen hukum yang ada saat ini belum cukup melindungi tenaga kesehatan termasuk bidan dalam melakukan pertolongan persalinan penderita HIV/AIDS belum sesuai dengan Pasal 57 Undang-Undang Republik Indonesia Nomor 36 Tahun 2014 tentang Tenaga Kesehatan. Tes HIV wajib ditawarkan pada ibu hamil sebagai sesuai dengan Surat Edaran Nomor GK/MENKES/001///2013 sangat menguntungkan bagi bidan karena dapat menjadi salah satu upaya perlindungan bidan dalam pertolongan persalinan penderita HIV/AIDS.
\end{abstract}

\section{Kata kunci: Perlindungan Hukum, Bidan, Pertolongan Persalinan, HIV/AIDS}

Abstract: The case of HIV / AIDS is an iceberg phenomenon meaning that its case emerges to surface only a fraction of the truth. Midwives carrying out childbirth assistance for patients who have HIVIAIDS have a high risk of contracting HIV/AIDS during childbirth assistance. This study aims at determining and analyzing the legal protection for midwives in the childbirth assistance of HIV/AIDS sufferers in terms of the Republic of Indonesia Law Number 36 Year 2014 concerning Health Workers. This study used a normative juridical approach. The specification of this study is descriptive analysis. The study used primary data in the form of data directly obtained from sources and secondary data consisting of primary legal materials, secondary legal materials, and tertiary legal materials. Data collection techniques used field studies and literature studies. Those data were analyzed using qualitative juridical methods. The results of conducted study required legal provisions that can protect midwives in childbirth assistance for patients with HIV/AIDS while the existing legal instruments are not sufficient to protect health workers including midwives in carrying out childbirth assistance for HIV/AIDS sufferers not in accordance with Article 57 of the Law of the Republic of Indonesia Number 36 Year 2014 concerning Health Workers. HIV testing must be offered to pregnant women as in accordance with Circular Letter Number 
GK/MENKES/001/I/2013 is very beneficial for midwives because it can be one of the efforts to protect midwives in childbirth assistance with HIV/AIDS.

Key words: Legal Protection, Midwives, Childbirth Assistance, HIV/AIDS

\section{A. PENDAHULUAN}

Di Indonesia penyebaran HIV/AIDS hampir merata di seluruh provinsi, hal ini terbukti dengan adanya laporan kasus AIDS di 27 provinsi dan infeksi HIV dari 29 provinsi di Indonesia. Data Kementerian Kesehatan pada tahun 2011 memperlihatkan sekitar 26.400 pengidap AIDS dan 66.600 pengidap HIV positif, lebih dari 70 persen generasi muda usia produktif 20-39 tahun. Data kementerian kesehatan (2011) menunjukkan dari $21.103 \mathrm{ibu}$ hamil yang menjalani tes HIV, 534 $(2,5 \%)$ diantaranya positif terinfeksi HIV. Penularan HIV dari ibu yang terinfeksi HIV ke bayinya juga cenderung meningkat seiring dengan meningkatnya jumlah perempuan HIV positif yang tertular baik dari pasangan maupun akibat perilaku yang beresiko. Salah satu penyebab kematian ibu dan bayi adalah persalinan dengan HIV/AIDS. Dalam proses pertolongan persalinan kewenangan bidan hanya menangani persalinan normal saja, maka dalam kasus persalinan dengan HIV/AIDS, bidan melakukan tugas kolaborasi dengan tenaga kesehatan lainnya, salah satunya melakukan rujukan kepada dokter spesialis kandungan untuk penanganan lebih lanjut. Tidak semua pasien HIV/AIDS mengetahui bahwa dirinya mengidap HIV/AIDS, bahkan pasien HIV/AIDS cenderung enggan memberikan informasi bahwa pasien mengidap HIV/AIDS dikarenakan sering terjadinya tindak diskriminasi pada pasien HIV/AIDS. Bidan Praktek Mandiri atau Bidan Desa dengan keterbatasan alat laboratorium akan lebih mudah terancam tertular HIV/AIDS pada saat melakukan pertolongan pada kelahiran bayi dengan ibu yang sudah positif mengidap HIV/AIDS. Bidan memberikan pelayanan kesehatan primer maka dari itu bidan memerlukan perlindungan hukum dalam menjalankan tugasnya memberikan pelayanan kesehatan dan jika terjadi hal yang tidak 
diinginkan. Uraian diatas membuat penulis merasa tertarik untuk melakukan penelitian dengan topik perlindungan hukum bagi bidan dalam proses pertolongan persalinan penderita HIV/AIDS ditinjau dari Undang - Undang Republik Indonesia Nomor 36 Tahun 2014 Tentang Tenaga Kesehatan.

\section{B. METODE}

Pendekatan yang digunakan dalam penelitian ini adalah pendekatan yuridis normatif, karena penelitian ini dilakukan dengan cara menghubungkan antara kaidahkaidah perundang-undangan yang ada sebagai norma hukum positif dengan pelaksanaan di masyarakat. Spesifikasi penelitian ini adalah deskriptif analisis, yang memberikan gambaran yang jelas tentang keadaan yang terjadi pada saat penelitian berlangsung yang tertuju pada analisa perkara perlindungan hukum bagi bidan dalam proses pertolongan persalinan penderita HIV/AIDS. Sebagai bahan pendukung penulisan ini, maka diperlukan data baik primer maupun sekunder. Data primer berupa data yang langsung diperoleh dari narasumber yang berkaitan dengan permasalahan dalam praktik yang nyata, yang diteliti dan dipelajari sebagai sesuatu yang utuh, yang dihubungkan dengan keadaan atau norma yang berupa peraturan dalam hukum perdata, hukum pidana, hukum administrasi yang berkaitan dengan perkara perlindungan hukum bagi bidan dalam proses pertolongan persalinan penderita HIV/AIDS.

\section{HASIL}

Situasi bidan di Indonesia pada tahun 2013 tercatat 300.000 orang dan yang tercatat di Ikatan Bidan Indonesia (IBI) sebanyak 178.000 orang. Di Provinsi Jawa Barat sebanyak 18.000 orang. Berdasarkan hasil wawancara dengan salah satu petugas Dinas Kesehatan Kota Cimahi data tahun 2017 di Kota Cimahi terdapat 5 kasus persalinan dengan HIV/AIDS, 1 kasus HIV/AIDS yang disertai dengan penyakit TB.

Di dalam modul pelatihan pencegahan penularan HIV dari ibu ke bayi, disebutkan bahwa kelompok risiko tinggi adalah golongan 
individu yang memiliki risiko tinggi untuk menularkan/tertular HIV/AIDS yang salah satu diantaranya adalah tenaga kesehatan yang sengaja atau tidak disadari berhubungan/terinfeksi dengan spesimen pasien HIV/AIDS. Tenaga kesehatan sangat berhubungan erat dengan sejumlah besar dan beragam mikroorganisme. HIV dan infeksi lain yang menular melalui darah meningkatkan kebutuhan perlindungan terhadap infeksi baik bagi bidan maupun ibu. Risiko infeksi HIV bagi tenaga kesehatan adalah rendah, tetapi bukan $0 \%$.

Proses keseluruhan dari manajemen risiko mencakup langkah-langkah identifikasi potensi bahaya, penilaian risiko dan pengendalian risiko. Upaya-upaya pengendalian harus dilaksanakan sesuai hirarkinya, berdasarkan efektifitasnya dalam mengeliminasi risiko, mencegah pajanan atau mencegah kesakitan. Semua aspek manajemen risiko akan lebih efektif dengan keterlibatan tenaga kesehatan.

Program pengendalian HIV tidak cukup hanya dilaksanakan oleh jajaran kesehatan saja namun harus pula melibatkan sektor lain dan masyarakat atau komunitas terutama populasi kunci. Pelibatan ini mulai dari upaya pencegahan di masyarakat hingga perawatan, dukungan dan pengobatan, sehingga program pengendalian HIV tersebut merupakan upaya kesehatan masyarakat dan juga sekaligus upaya kesehatan perorangan.

Pengobatan anti retro viral (ARV) di Indonesia pada awalnya diinisiasi di rumah sakit (RS). Pedoman tatalaksana HIV dan pengobatan antiretroviral telah lama tersedia dan terus menerus diperbarui sesuai dengan perkembangan ilmu pengetahuan, untuk digunakan sebagai pedoman dalam memberi layanan kepada ODHA. Dengan makin bertambahnya jumlah kasus HIV dan meningkatnya kebutuhan akan adanya akses layanan yang menyebar secara luas sehingga semua orang dengan HIV dapat dengan mudah memulai ARV di dekat lingkungan tinggalnya maka akses layanan perlu didekatkan ke masyarakat. 
Sejumlah program yang dilakukan untuk menekan pertumbuhan penyakit HIV AIDS di Kota Cimahi. Salah satunya menerapkan program Voluntary Counseling Testing (VCT) dan Care Support Treatment (CST) yang dilakukan di Rumah Sakit Umum Daerah (RSUD) Cibabat dan Puskesmas. Dalam pelaksanaanya Kota Cimahi bekerja sama dengan Komisi Penanggulangan HIV AIDS dan beberapa LSM. Karena masih terkendala faktor sumber daya manusia, maka pelayanan VCT ini untuk sementara tidak dapat dilakukan di semua wilayah Cimahi. Meskipun layanan VCT ini baru dapat dilakukan di Puskesmas, namun ada juga LSM yang membuka layanan tersebut, dalam menjalankan layanan VCT dan CST di Cimahi juga dibantu oleh Klinik Mawar milik LSM PKBI Jawa Barat. Rumah Sakit Umum Daerah (RSUD) Cibabat telah memiliki layanan VCT, tapi kurang tersosialisasikan. Oleh karena itu, masyarakat relatif kurang banyak memanfaatkan layanan VCT di RSUD Cibabat.

\section{PEMBAHASAN}

1. Peraturan Daerah Merupakan Payung Hukum Yang Efektif Bagi Perlindungan Bidan Dalam Proses Persalinan Penderita HIV/AIDS Menurut Undang-Undang Nomor 36 Tahun 2014 Pasal 57 tentang Tenaga Kesehatan

Dalam rangka penyelenggaraan pemerintah daerah sesuai amanat UndangUndang Dasar Negara Republik Indonesia Tahun 1945, pemerintah daerah yang mengatur dan mengurus sendiri urusan pemerintahan menurut asas otonomi dan tugas pembantuan diartikan untuk mempercepat terwujudnya kesejahteraan masyarakat melalui peningkatan, pelayanan, pemberdayaan dan peran serta masyarakat.

Sistem pemerintahan Indonesia menurut UUD 1945 memberikan keleluasaan kepada daerah untuk menyelenggarakan otonomi daerah. Dalam penyelenggaraan otonomi daerah, dipandang perlu untuk lebih menekankan pada prinsip- 
prinsip demokrasi, peran serta masyarakat, pemerataan dan keadilan, serta memperhatikan potensi dan keanekaragaman daerah. Oleh karenanya, penyelenggaraan otonomi daerah adalah dengan memberikan kewenangan yang luas, nyata, dan bertanggung jawab kepada daerah secara proporsional. Perda menempati kedudukan kuat dalam otonomi luas, tapi terhadapnya berlaku juga pengawasan, dengan maksud agar jangan sampai ada Perda yang melampaui batas proporsional kewenangan atau merugikan kepentingan umum.

Peraturan daerah ini dibutuhkan agar setiap langkah untuk penanggulangan dan pencegahan HIV/AIDS seperti pada saat bidan dalam proses pertolongan persalinan penderita HIV/AIDS di lapangan memiliki payung hukum sebagai acuan perlindungan hukum.

2. Peran Pemerintah Terhadap Hak Perlindungan Hukum Bagi Bidan Dalam Proses

\section{Pertolongan \\ Persalinan}

\section{Penderita HIV/AIDS}

Bermacam peraturan dan kebijakan nasional merupakan kerangka kerja untuk aksi yang berkaitan dengan HIV/AIDS dan pelayanan kesehatan. Kerangka kerja ini termasuk kebijakan sektor kesehatan nasional dan AIDS, peraturan ketenagakerjaan, peraturan dan standar $\mathrm{K} 3$, peraturan antidiskriminasi dan peraturan perundangan yang diterapkan kepada sektor kesehatan.

Tanggung jawab pemerintah adalah menjamin pendekatan yang terkoordinasi antara semua sektor, untuk mempromosikan dan mendukung standar pelayanan kesehatan setinggi mungkin dalam pelayanan kesehatan, khususnya dalam segi persyaratan kerja dan perawatan pasien, serta mengalokasikan sumber daya dan dana yang cukup. Keberhasilan perencanaan dan penerapan kebijakan nasional dan peraturan perundangan membutuhkan konsultasi yang luas antara pengusaha pelayanan kesehatan, pekerja dan perwakilannya, asosiasi 
profesional, ODHA dan para pihak terkait lainnya, dan sistem penegakan hukum yang efektif.

Khusus dalam sektor kesehatan, pemerintah pada waktu yang sama adalah regulator, penegak hukum dan juga pengusaha. Harus dijamin bahwa fungsi-fungsi ini tetap terpisah untuk meminimalisir konflik kepentingan dan melindungi hak-hak tenaga kerja secara memadai. Dalam perannya sebagai pengusaha (pelayanan kesehatan milik pemerintah), pemerintah harus menjaga konsultasi dan kerjasama yang baik dengan organisasi pengusaha swasta dan organisasi pekerja kesehatan. Pemerintah harus menjamin agar terdapat lembaga pengawasan K3 dengan anggaran yang memadai, untuk memberikan panduan dan menegakkan peraturan K3.

Suatu sistem Keselamatan dan Kesehatan Kerja (K3) yang efektif memerlukan komitmen bersama antara pihak yang kompeten, pengusaha, pekerja dan perwakilan mereka. Tanggung jawab menyeluruh untuk memberikan lingkungan kerja yang aman dan sehat terletak pada pengusaha, yang harus menunjukkan komitmennya kepada K3 dengan menempatkan suatu program yang terdokumentasi, tersedia bagi pekerja dan perwakilan mereka, yang menjelaskan prinsipprinsip pencegahan, identifikasi potensi bahaya, penilaian dan pengendalian risiko, informasi dan pelatihan. Pekerja mempunyai tugas untuk bekerja sama dengan pengusaha dalam menerapkan $\mathrm{K} 3$, menghargai dan menjalankan prosedur dan instruksi lainnya yang dirancang untuk melindungi mereka dan orang lain yang berada di tempat kerja, terhadap pajanan potensi bahaya akibat pekerjaan. Panitia Pembina Keselamatan dan Kesehatan Kerja (P2K3) adalah mekanisme yang diakui dimana kolaborasi diatas dapat dicapai.

Penyediaan perawatan, pengobatan dan dukungan bagi tenaga kesehatan yang terinfeksi atau terkena dampak HIV/AIDS akan mengurangi kerugian tenaga terampil dan berpengalaman, dan meminimalisir gangguan pelayanan. Hal ini juga menghargai hak-hak pekerja untuk tetap di lapangan kerja 
selama mereka mampu untuk bekerja, membantu untuk mempertahankan pendapatan mereka, dan menyumbang pada kesejahteraan mereka. Sedapat mungkin, pengusaha harus memfasilitasi akses kepada perawatan, pengobatan dan dukungan yang komprehensif, yang mengkombinasikan ketentuanketentuan khusus bagi pekerja yang sakit atau mempunyai anggota keluarga yang sakit, dengan ketentuan umum sebagai bagian dari perlindungan sosial. Unsur-unsur kunci dari program tersebut adalah konseling dan tes sukarela (Voluntary Counselling and Testing VCT).

Tes sukarela bagi pekerja kesehatan yang ingin mengetahui status HIV mereka haruslah didorong dan disediakan. Dimana terdapat pelayanan medis yang cukup, tes sukarela dapat dilaksanakan bila diminta dan, bila perlu dengan pernyataan persetujuan (informed consent) tertulis dari pekerja dan dengan panduan dari perwakilan mereka bila diminta.
Penerimaan terhadap tes HIV tergantung pada perlindungan terhadap stigma dan diskriminasi, begitu juga jaminan akses kepada pelayanan terpadu untuk pencegahan, pengobatan dan perawatan. Menurut prinsip-prinsip kunci dari tes HIV dikenal sebagai "3Cs", tes harus disediakan dengan dasar pernyataan persetujuan - informed consent, dan disertai dengan koseling counseling, dan kerahasiaan confidentiality harus dijamin.

Pemerintah sedang melakukan sosialisasi upaya pencegahan HIV/AIDS yang tertera dalam Surat Edaran Nomor GK/MENKES/001/I/2013 Tentang Layanan Pencegahan Penularan HIV Dari Ibu Ke Anak (PPIA) dijelaskan bahwa Tes HIV wajib ditawarkan pada semua ibu hamil di daerah epidemi HIV meluas dan terkonsentrasi, $\quad$ Tes HIV diprioritaskan untuk ditawarkan pada ibu hamil dengan IMS dan TB di daerah epidemi HIV rendah dan Tes HIV pada ibu hamil dilaksanakan bersamaan dengan pemeriksaan laboratorium rutin lainnya. Upaya tersebut juga sangat efektif bagi 
bidan sebagai upaya perlindungan bidan dalam proses pertolongan persalinan, jika pasien tersebut diketahui mengidap HIV/AIDS sebagai bidan praktik mandiri dan puskesmas dapat melakukan rujukan ke rumah sakit untuk mendapatkan penanganan lebih lanjut, pihak rumah sakit dapat memberikan pengobatan yang sesuai. Walaupun di lapangan masih terdapat beberapa kendala dalam pelaksanaannya dikarenakan pemerintah yang belum maksimal dalam memenuhi fasilitas sarana, prasarana dan kurangnya sumber daya manusia yang terlatih VCT.

\section{E. SIMPULAN}

Dari uraian hasil penelitian dan pembahasan dalam bab terdahulu didapatkan simpulan bahwa Instrumen hukum yang ada saat ini belum cukup melindungi tenaga kesehatan termasuk bidan dalam melakukan pertolongan persalinan penderita HIV/AIDS belum sesuai dengan Pasal 57 Undang - Undang Republik Indonesia No. 36 Tahun 2014 tentang Tenaga Kesehatan, bahwa salah satu hak tenaga kesehatan dalam memberikan pelayanan kesehatan, yaitu memperoleh perlindungan hukum sepanjang melaksanakan tugas sesuai dengan Standar Profesi, Standar Pelayanan Profesi, dan Standar Prosedur Operasional. Perlindungan hukum bagi bidan dalam pertolongan persalinan penderita HIV/AIDS adalah dengan menerapkan pedoman pencegahan HIV/AIDS. Peran pemerintah terhadap perlindungan hukum bagi bidan dalam proses pertolongan persalinan penderita HIV/AIDS di Kota Cimahi saat ini belum terlaksana dengan baik terbukti dengan belum adanya peraturan daerah tentang pengendalian HIV/AIDS. Tes HIV wajib ditawarkan pada ibu hamil sebagai sesuai dengan Surat Edaran Nomor GK/MENKES/001/I/2013 sangat menguntungkan bagi bidan karena dapat menjadi salah satu upaya perlindungan bidan dalam pertolongan persalinan penderita HIV/AIDS tetapi saat ini belum terlaksana secara merata dikarenakan kurangnya tenaga kesehatan yang terlatih dan kurangnya sarana dan 
Pemi Novita Sari, Perlindungan Hukum Bagi Bidan Dalam Pertolongan Persalinan Penderita...

prasarana di fasilitas kesehatan tingkat pertama.

\section{F. SARAN}

1. Guna meminimalisir kendalakendala bidan dalam proses pertolongan persalinan penderita HIV/AIDS di lapangan hendaknya ada kata sepakat atau pun pemahaman yang sama untuk menerapkan pedoman pencegahan HIV/AIDS sebagai upaya perlindungan bagi bidan dalam proses pertolongan persalinan penderita HIV/AIDS.

2. Pemerintah dapat segera merealisasikan pembuatan peraturan daerah tentang pencegahan dan penanggulangan HIV/AIDS yang didalamnya juga dijelaskan tentang perlindungan bagi tenaga kesehatan salah satunya yaitu Tes HIV wajib ditawarkan pada semua ibu hamil sebagai upaya perlindungan hukum bagi bidan sesuai dengan Surat Edaran Nomor

GK/MENKES/001/I/2013

Tentang Layanan Pencegahan
Penularan HIV Dari Ibu Ke Anak (PPIA).

\section{DAFTAR PUSTAKA}

\section{A. Buku - Buku}

Achmad Ali, Menguak Teori Hukum dan Teori Peradilan, Prenada Media Grup, Jakarta, 2009.

Bahder Johan Nasution, Hukum Kesehatan

Pertanggungjawaban Dokter, Rineka Cipta. Jakarta. 2005. Bagir Manan, Menyongsong Fajar Otonomi Daerah, Pusat Studi Hukum, Yogyakarta, 2001.

Christian, R, Aspek Hukum Kesehatan Dalam Upaya Medis Transplantasi Organ Tubuh, Universitas Atmajaya, Yogyakarta, 2003.

Chuzaimah Tahido Yanggo, Hafidz Anshory, Problematika Hukum Islam, Pustaka Firdaus, Jakarta, 2002 
CST Kansil, Pengantar Hukum

Kesehatan Indonesia, Rineka

Cipta, Jakarta, 1991.

Denise Tiran, Kamus Saku Bidan

Ed.10, EGC, Jakarta, 2005.

Departemen Kesehatan Republik

Indonesia, Pencegahan

Penularan HIV dari Ibu ke

Bayi, Jakarta, 2008.

Departemen Kesehatan Republik

Indonesia, Sistem Kesehatan

Nasional, Jakarta, 2009.

Diana Halim Koentjoro, Hukum

Administrasi Negara, Ghalia

Indonesia, Jakarta, 2004.

Dirjen Pemberatasan Penyakit

Menular dan Penyehatan

Lingkungan Depkes RI,

Pedoman Nasional

Perawatan Dukungan dan

Pengobatan Bagi ODHA,

Depkes RI, Jakarta, 2003.

Helen Varney, Jan M. Kriebs, Carolyn L. Gegor, Buku Ajar
Asuhan Kebidanan Edisi 4, EGC, Jakarta, 2007.

Heni Puji Wahyuningsih, Asmar Yetty Zein, Etika Profesi Kebidanan, Fitramaya, Yogyakarta, 2005.

Ida Bagus Manuaba, Praktik dan Registrasi Bidan, EGC, Jakarta, 2000.

Ishaq, Dasar-dasar Ilmu Hukum, Sinar Grafika, Jakarta, 2009.

Juhaya S Praja, Filsafat Hukum Islam, LPPM UNISBA, Bandung, 1995.

Komite Penanggulangan AIDS Daerah Kota Bandung, Situasi HIV/AIDS di Kota Bandung, KPAD, Bandung, 2006.

Komite Penanggulangan AIDS Jawa Barat, Laporan Tahunan, KPA Jawa Barat, Bandung, 2016. 
Lexy J Maelong, Metodologi Penelitian Kualitatif, PT Remaja Rosdakarya,

Bandung, 2000.

Maria Farida Indrati Soeprapto,

Limu Perundang-Undangan

Dasar-Dasar

Pembentukannya, Kanisius, Jakarta, 2005.

Marwan Mas, Pengantar Ilmu Hukum, Ghalia Indonesia, Jakarta, 2004.

Muchsin, Perlindungan dan Kepastian Hukum Bagi Investor di Indonesia, Universitas Sebelas Maret, Surakarta, 2003.

Notoatmodjo S, Pendidikan dan Perilaku Kesehatan, Rineka Cipta, Jakarta, 2003.

Pengurus Pusat Ikatan Bidan Indonesia, Modul Midwifery Update, PP IBI, Jakarta, 2017.

Mastuhu, M. Deden Ridwan, Tradisi Baru Penelitian Agama Islam:Tinjauan Antar Disiplin Ilmu, Penerbit Nuansa, Bandung, 1998.

Pengurus Daerah Ikatan Bidan Indonesia, Pengembangan Keprofesian Berkelanjutan, PD IBI Jawa Barat, Bandung, 2017.

Masyhur Effendi, Dimensi dan Dinamika Hak Asasi Manusia dalam Hukum Nasional dan Internasional, Ghalia Indonesia, Jakarta, 1994.

Moh. Mahfud MD. Membangun Politik Hukum, Menegakkan Konstitusi, LP3ES, Jakarta, 2006.

Peter Mahmud Marzuki, Pengantar Ilmu Hukum, Kencana, Jakarta, 2008.

Philipus M. Hadjon, Perlindungan Hukum Bagi Seluruh Rakyat Indonesia, Bina Ilmu, Surabaya, 1987. 
Ria Anjarwati dkk, Buku Ajar

Konsep Kebidanan, Buku

Kedokteran EGC, Jakarta,

2006

Rury Narulita Sari, Konsep

Kebidanan, Graha Ilmu,

Yogyakarta, 2012.

Rusly Effendy, Teori Hukum,

Universitas Hasannudin

Press, Ujung Pandang, 1991.

Safitri Hariyani, Sengketa Medik

Alternatif Penyelesaian

Perselisihan Antara Dokter

Dengan Klien, Diadit Media,

Jakarta, 2005.

Saifuddin Bari, Buku Acuan

Nasional Pelayanan

Kesehatan Maternal Dan

Neonatal, Yayasan Bina

Pustaka Sarwono

Prawirohardjo, Jakarta, 2006.

Satjipto Rahardjo, Ilmu Hukum,

Citra Aditya Bakti, Bandung, 2000 .
Setiono, Rule of Law (Supremasi Hukum), Magister Ilmu Hukum Program Pascasarjana Universitas Sebelas Maret, Surakarta, 2004.

Sirajudi, Fatkhurohman, Zulkarnain, Legislatif dalam Pembentukan PerundangUndangan, YAPPIKA, Jakarta, 2007.

Soerjono Soekanto, Pengantar Penelitian Hukum, UI Press, Jakarta, 1987.

Sofyan dkk, Bidan Menyongsong Masa Depan, PP-IBI, Jakarta, 2006.

Suharsimi Arikunto, Prosedur Penelitian Suatu Pendekatan Praktek Edisi Revisi IV, PT Rineka Cipta, Jakarta, 1998.

Suzana Murni, Hidup Dengan HIV/AIDS, Yayasan Spiritia, Jakarta, 2016.

Tim ICCE UIN Jakarta, Demokrasi, Hak Asasi 
Manusia dan Masyarakat

Madani, Prenada Media,

Jakarta, 2003.

Tim Kementerian Lingkungan

Hidup, Pedoman Kriteria

Teknologi Pengelolaan

Limbah Medis Ramah

Lingkungan, Tim KLH,

Jakarta, 2014.

Veronica Komalawati, Hukum

Dan Etika Dalam Praktik

Dokter, Sinar Harapan,

Jakarta, 1989.

WHO,ILO, Pedoman Bersama

ILO/WHO tentang Pelayanan

Kesehatan HIV/AIDS, Direktorat

Pengawasan Kesehatan Kerja,

Jakarta, 2005.

Wila Chandrawila, Hukum Kedokteran, Mandar Maju, Bandung, 2001.

Yatim, Danny Irawan, Dialog Seputar AIDS, Gramedia Widiasarana Indonesia, Jakarta, 2006.
Yusuf Shofie, Perlindungan Konsumen dan InstrumenInstrumen Hukumnya, Citra Aditya Bhakti, Bandung, 2009.

Zainuddin Ali, Metode Penelitian Hukum, Sinar Grafika, Jakarta, 2009.

Zein, Umar, dkk, 100 Pertanyaan Seputar HIV/AIDS Yang Perlu Anda Ketahui, USU press, Medan, 2006.

\section{B. Jurnal dan Makalah}

Fadlansyah, Pengidap HIV/AIDS Butuh Perlindungan Hukum, Universitas Gajah Mada, Yogyakarta, 2012.

Rusman Tumanggor, "MasalahMasalah Sosial Budaya Dalam Pembangunan Kesehatan Di Indonesia”, Jurnal Masyarakat dan Budaya Jakarta Vol 12 No.2, Lembaga Ilmu Pengetahuan Indonesia, Pusat Penelitian 
Kemasyarakatan dan

Kebudayaan, 2010.

Sugi Purwanti, Dyah Fajarsari,

Rohmi Handayani,

“Determinan Perilaku Bidan

Dalam Pencegahan Infeksi

Hiv Aids Pada Pertolongan

Persalinan Di Kabupaten

Banyumas", Jurnal Ilmiah

Kebidanan, Vol. 5 No. 2

Edisi Desember 2014.

Tedi Sudrajat dan Agus

Mardianto, Hak Atas

Pelayanan dan

Perlindungan Kesehatan Ibu

dan Anak (Implementasi

Kebijakan Di Kabupaten

Banyumas). Jurnal Dinamika

Hukum Vol. 12 No.2,Mei

2012.

Wulan Mayasari, Sofwan Dahlan

dan Yovita Indrayati,

Perlindungan Hukum

Terhadap Masalah

Tertularnya Hiv/AIDS Dan

Hepatitis B Dalam

Pemberian Pelayanan

Kesehatan Bagi Peserta
Program Pendidikan Profesi

Dokter (P3D) Di Bandung,

Soepra Hukum Kesehatan

Vol. 1 No.2. Magister

Hukum Kesehatan

Universitas Katolik

Soegijapranata, Semarang, 2015.

Noveri Aisyaroh, Ita Listiyana dan Afriyanti, Praktik Universal Precautions Bidan Dalam Pencegahan Hiv/Aids Pada Pertolongan Persalinan Di Rumah Sakit, Dekatutari Universitas Islam Sultan Agung, Fakultas Ilmu Kesehatan, Jurnal Ilmiah Kebidanan, Vol.3 No.2, Semarang, 2012.

\section{PERUNDANG}

\section{UNDANGANAN}

Undang-Undang Dasar Negara

Republik Indonesia Tahun 1945

Undang-Undang Nomor 39

Tahun 1999 tentang Hak Asasi

Manusia 


\author{
Undang-Undang Republik \\ Indonesia Nomor 36 Tahun 2009 \\ tentang Kesehatan
}

Undang-Undang Republik

Indonesia Nomor 36 Tahun

2014 Tentang Tenaga

Kesehatan

Peraturan Menteri Kesehatan

Republik Indonesia Nomor

51 Tahun 2013 Tentang

Pedoman Pencegahan

Penularan HIV Dari Ibu Ke

Anak

Peraturan Menteri Kesehatan

Republik Indonesia Nomor

28 Tahun 2017 Tentang Izin

dan Penyelenggaraan

Praktik Bidan

D. Lain - Lain

(http://imamah03.blogdetik.com/

2012/01/11/perencanaan-

bidan-Praktik-mandiri-

bpm/) Diakses pada tanggal

02 November 2017
Komisi Penanggulangan AIDS, 2007. Apa Gejala Orangorang yang Terinfeksi HIV menjadi AIDS. Diakses di http://AIDSina.org/modules. php?name=FAQ \&MYFAQ $=$ YES\&idcat=1\&categories $=$ HIV-AIDS, pada tanggal 28 November 2017, pukul 19.47

Laporan Dinas Kesehatan Kota Cimahi Tahun 2016 diakses di

http://www.cimahikota.go.i d/news/detail/1511 tanggal 9 Juni 2017 jam 12.30

Lembaran fakta mengenai HIV/AIDS bagi perawat dan bidan, World Health Organization, Geneva, 2000 (http://www.who.int/healthservices-delivery/hiv-aids/). Diakses pada tanggal 27 Desember 2017

Profil Kota Cimahi diakses di http://www.cimahikota.go.i d/page/detail/1 tanggal 10 Juli 2017 jam 18.00 
Pemi Novita Sari, Perlindungan Hukum Bagi Bidan Dalam Pertolongan Persalinan Penderita...

Wilburn QS, BSN, MPH,

Waspada Bidan Rentan Tertular

HIV /AIDS diakses di

http://jambi.tribunnews.com

/2011/06/21/waspada-bidan-

rentan-tertular-hivaids

pada tanggal 07 Agustus

$\underline{2017}$ jam 18.00
Eijkemans G, dkk. 2004,

Preventing Needlestick

Injuries Among Healthcare

Workers, Diakses di

http://www.ijoeh.com pada

tanggal 5 November 2017 
Pemi Novita Sari, Perlindungan Hukum Bagi Bidan Dalam Pertolongan Persalinan Penderita... 